\title{
Rumpf 式の新たな解釈とその応用
}

椿淳一郎*

Jun-ichiro TSUBAKI
はじめに

粉体層の挙動を力学的に解析する場合, 実際に測定で きるのは応力であり, 粒子接触点に働く力の測定はほと んぞの場合不可能である。しかし，粒子接触点に働く力 を求めたくなる場合が少なからずあるし，また求めるこ とができれば粉体層の力学的挙動の解明に対して有効な 武器となる。そのため, 粉体層に作用する応力と粒子接 触点に働く力の関係式が，これまでいくつか提案されて きた。その中でも，粉体層引張り強さと接触点に働く付 着力の関係を求めた Rumpf 式は有名である。

ここでは，これまで提案されている関係式を詳しく紹 介するとともに，Rumpf 式に対して新たな意味づけを 行ない，その応用例をいくつか紹介する。

1. 応カとカの関係を表す理論式

(1)式に示す Rumpf 式) は，粉体層の引張り強さに関 する理論式として広く知られている。

$$
\sigma_{z}=\frac{1-\varepsilon}{\pi} k \frac{H}{d^{2}}
$$

一方, 応力と力の関係式がいくつが, ${ }^{3,6}$ 理諭的唀導 されている。本章に拉いては，それらのいずれもが(1)式 に一致し，したがって Rumpf 式は引張り強さに関する 式でなく，応力と力の関係を表す一般式であることを示 ఫे。

\subsection{Rumpf ${ }^{1,2)}$ ，Molerus ${ }^{3)}$ の考え方}

ここでは, Molerus の論文に沿って説明する。

まず, 粉体層, 応力に対して次の仮定を監く。

i）粉体㬝は, 半径 $r$ (直径 $d$ ) の均一球によってラン ダムに充てんされている。

ii）応力は静水圧のように等方的に作用している。

粉体層に作用する応力を求めるためには, 粉体層中に 平面を考えなければならない。いまその平面を，Fig.1

昭和58年10月 5 日受付

* 名古屋大学工学部化学工学科(

TE L 052-781-5111

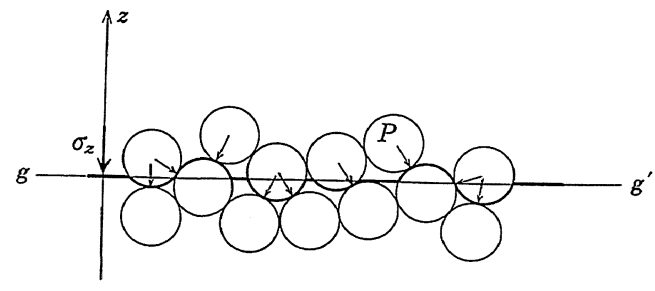

Fig. 1 粉体層の中の平面

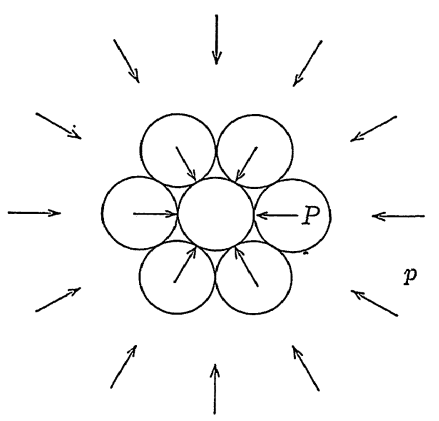

Fig. 2 静水王の応力と圧縮力の分布

に2 次元的に示すように, $\overline{g g^{\prime}}$ とする。しかし，実際の 応力伝達は，Fig.1 に太線で示した曲面 $\widetilde{g} g^{\prime}$ 上の接触 点に拈いて行なわれ，これらの接触点はすべて平面 $\overline{g g^{\prime}}$ が横切る球 (以下切断球之略称) 上にある。したがっ て，次のように考えれば，応力と力を関係づけることが できる。

$$
\text { 応力 }=\frac{\text { 球の個数 }}{\text { 単位面積 }} \times \frac{\text { 応力方向に働く力 }}{1 \text { 個の球 }}
$$

(2)式を実際に計算するために，粉体層を次のように平 均化して考光る。切断球は, Fig.1からも明らかなよう に，様々な位置で他の球と接触し，その接触球の数もま ちまちである。しかし，切断球をすべて重ね合れせれ ば，ランダム充てんを仮定しているので，接触球は Fig. 2 に示すように, 切断球の回りに一様に分布してい ることになる。このように粉体層を統計的に平均化して 考学れば，応力が等方的に作用するとき，各接触点に働 く力も等方的になり, 切断球の中心に向って同じ大きさ で働くと考兄れる。 


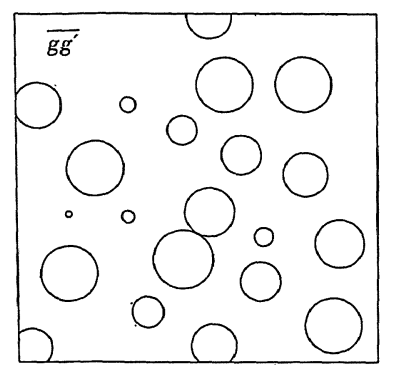

Fig. 3 均一球で充てんされた粉体層の切断面

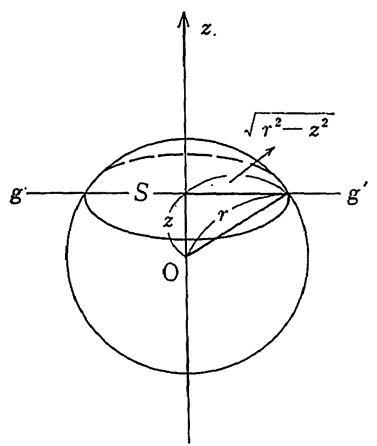

Fig.4 切断された球粒子

まず, (2)式右辺第 1 項, 単位面積当りの切断球の個数 を求める。平面 $\overline{g g^{\prime}}$ による切断面は，Fig. 3 のように 得られる。球の半径はrで一定であるが，切断される位 置によって切断面に表れる円の半径は，０からとまで变 化する。いま, Fig. 4 に示すように, 中心から $z$ の位置 で球を切ったとすると，その切断円の面積 $S$ は次式で与 えられる。

$$
S=\pi\left(r^{2}-z^{2}\right)
$$

したがって, Fig. 3 に示した平面 $\overline{g g^{\prime}}$ 上の切断円の平 均面積

$$
\bar{S}=\frac{1}{r} \int_{0}^{r} S \mathrm{~d} z=\frac{2 \pi r^{2}}{3}=\frac{\pi d^{2}}{6}
$$

一方, 均一球のランダム充てんにおいては， 3 次元空 吵率之 2 次元空吵率は等しいので, 平面 $\overline{g g^{\prime}}$ 上の 単位 面積中の切断円面積の総和は $1-\varepsilon$ になる。よって, 切 断面単位面積当りの球の数 $n$ は次式で与兄られる。

$$
n=\frac{1-\varepsilon}{\bar{S}}=\frac{6(1-\varepsilon)}{\pi d^{2}}
$$

次に，(2)式右辺第 2 項, 切断球 1 個に働く応力方向の 力は次のように考觉ることによって求められる。

\section{応力方向に働く力} 1 個の球

$=\left(\frac{\text { 接触点数 }}{\text { ある位置の切断球 }} \times \frac{\text { 力の応力方向成分 }}{1 \text { 接触点 }}\right) の$ 平均

Vol. 21 No. 1 (1984)

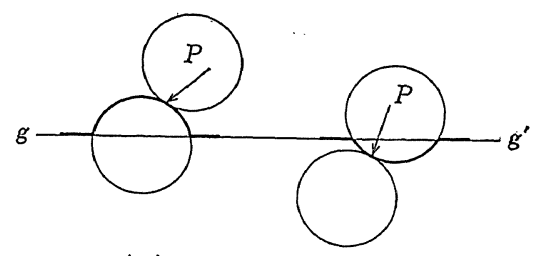

(a)

(b)

Fig. 5 力の働き方

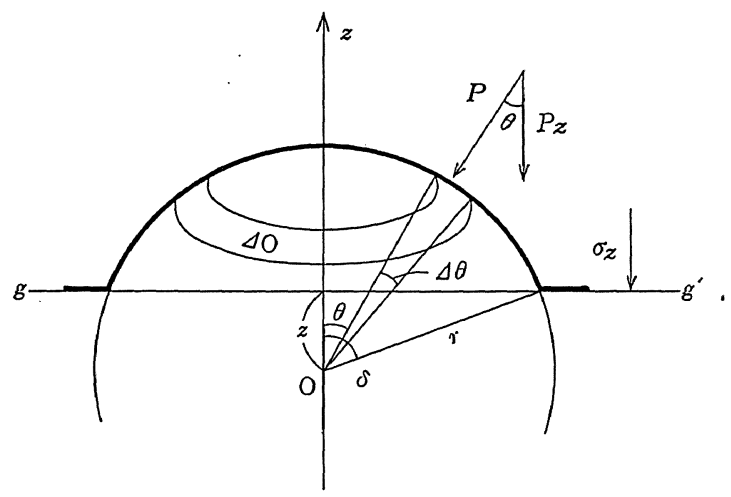

Fig. 6 切断球使倒く $z$ 方向の力

(6)

(6)式を求める前に，次のことを考虙しなければならな い。Fig. 5 に改めて示したように，曲面 $\widetilde{g g^{\prime}}$ 上の接触 点に働くカには 2 通りあることである。一つは，接触球 から切断球に働く力であり, むら一つは这に切断球から 接触球に働く力である。前者の場合，切断球の中心恃平 面 $\overline{g g^{\prime}}$ の下にあり，後者の場合は上にある。しか乙両 者の存在割合は，ランダム充てんを仮定しているのでま ったく等しい，また力が切断球から接蟲球に倒く場合で もその逆の場合でも，作用反作用の法則からその大きさ はまったく一致する。したがって，Fig.5(a)，(b)に示す どちらか一方では切断球と接触球の力学的関係は代表で きることになる。以下では，Fig.5 の(a)の場合で説明を 進める。

切断される球は平面 $\overline{g g^{\prime}}$ に対して0から 離をとりらるが，いまFig.6亿示すようにくの距耀の 切断球を考光，この球で平面 $\overline{g g^{\prime}}$ の上方にある球冠 (曲 面 $\widetilde{g} g^{\prime}$ に接する部分) の平均接触点数を求める。球冠 上飞 Fig. 6 示すような帯を考えると，その面積 $\Delta O$ は 次式で与えられる。

$$
\Delta O=2 \pi r \sin \theta \cdot r \Delta \theta
$$

平均配位数を $k$ とすれば, $\Delta O$ 上の接触点数 $\Delta k_{0}$ は次式 で与えられる。 


$$
\Delta k_{0}=\frac{\Delta O}{4 \pi r^{2}} k=\frac{k \sin \theta \Delta \theta}{2} .
$$

また, 帯 $\Delta O$ 上に働く力の応力方向すなわち $z$ 方向成分 は，次式で与えられる。

$$
P^{2}=P \cos \theta
$$

よって带 $\Delta O$ 上に働く力の $z$ 方向の総和 $\Delta F$ は，(8), (9) 式の積で与えられるので次式となる。

$$
\Delta F=\Delta k_{0} P^{2}=\frac{k P \sin 2 \theta \Delta \theta}{4}
$$

さらに, Fig.6から明らかなとらり, $\theta$ は曲面 $\widetilde{g} g^{\prime}$ の範

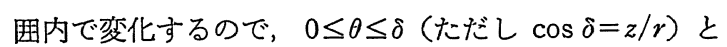
なる。したがって, 平面 $\overline{g g^{\prime}}$ から $z$ の距離にある球に 働く $z$ 方向の力 $F$ は，(10)式を 0 から $\delta$ まで積分すれば 得られることになる。

$$
F=\frac{k P}{4} \int_{0}^{\delta} \sin 2 \theta \mathrm{d} \theta=\frac{k P}{4 r^{2}}\left(r^{2}-z^{2}\right)
$$

また， $z$ は0から $r$ までとりらるので，Fの $z$ に対する 平均 $\bar{F}$ を求め机ば，切断球 1 個に作用する $z$ 方向の力 の平均，すなわち(6)式を求めたことになる。

$$
\bar{F}=\frac{1}{r} \int_{0}^{r} F \mathrm{~d} z=\frac{k P}{6}
$$

以上で，(2)式右辺の各項は求められたので，(5)，(12)式 を(2)式に代入すれば，次の結果を得る。

$$
\sigma_{z}=\frac{1-\varepsilon}{\pi} k \frac{P}{d^{2}}
$$

(13)式で， $P$ を接触点に働く付着力 $H$ で置き換え， $\sigma_{z}$ を粉体層引張り強さとしたのが Rumpf 式である。 Rumpf は，1958年と1967年にこの考え方に基ずいた誘

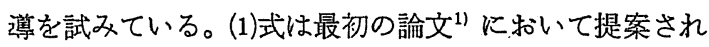
ているが, 誘導過程にいくつか誤りが含まれていた。2

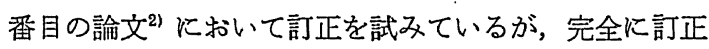
されずに（1)式の右辺に $9 / 8$ の保数の掛った式を提案し ている。Rumpf らが最終的に(1)式を導出した考え方は, 次に紹介するように実に簡潔なるのであった。

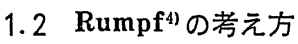

Rumpf は1970年に，以下の考え方によって最終的に Rumpf 式を導出したのであるが，意外にも国内におい てはRumpf 式の紹介や解説は，1967年の誤りを含ん だ論文 ${ }^{21}$ 基ずいて行なわれていたようである。

この考方标いても，均一球によって充てんされた 粉体層を仮定し，応力は等方的であるとしている。ま た，Fig.6亿示した切断球に着目して解析を進めている 点も，1.1で紹介した考方方と同様である。

Fig. 7 に示すよらに，切断球の表面に带 $\Delta O$ を考光る と，図から明らかなと拉り，この $\Delta O$ の平面 $\overline{g g^{\prime}}$ 上への 投影面積 $\Delta S$ は,

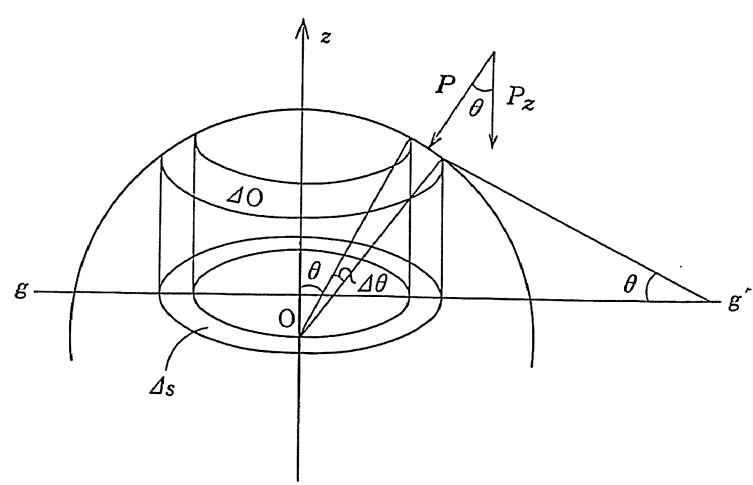

Fig. $7 z$ 方向から切断球と平面に働く力

$$
\Delta S=\cos \theta \Delta O
$$

で与兄られる。一方, 帯 $\Delta O$ 上の平均接触点数 $\Delta k_{0}$ は, (8)式と同様に,

$$
\Delta k_{0}=\frac{\Delta O}{\pi d^{2}} k
$$

で与えられる。また，帯 $\Delta O$ 上に働く力の $z$ 方向成分の 総和 $\Delta F$ は，(10)式同様次式で与えられる。

$$
\Delta F=\Delta k_{0} P^{z}=\frac{k P}{\pi d^{2}} \cos \theta \Delta O
$$

ここで，(14)式の関係を用いて(16)式の $\cos \theta \Delta O$ を消去す れば,

$$
\Delta F=\frac{k P}{\pi d^{2}} \Delta S
$$

が得られる。この(17)式は, 平面 $\overline{g g^{\prime}}$ 上に働く力が切断球 の切断面積に比例することを表している。したがって(17) 式の右辺を平面 $\overline{g g^{\prime}}$ 上の単位面積中に占める切断球の 面積 $1-\varepsilon$ まで積分すれば, 左辺の力 $\Delta F$ は単位面積に 働く力となるので応力 $\sigma_{z}$ と書き改めることができ， Rumpf 式(18)式を求めることができる。

$$
\begin{aligned}
\sigma_{z} & =\frac{k P}{\pi d^{2}} \int_{0}^{1-\varepsilon} \mathrm{d} S \\
\therefore \quad \sigma_{z} & =\frac{1-\varepsilon}{\pi} k \frac{P}{d^{2}}
\end{aligned}
$$

もちろん Rumpf の論文においては圧縮力は想定して おらず，接触点に働くカとしては付着力，応力としては 引張り強さのみを想定している。

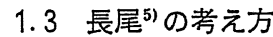

これまで紹介してきた考え方においては，粉体層に剪 断応力が作用しない等方応力烺定されていたのに対し て, 長尾の考光方は剪断応力も含め応力一般が扱光る点 ですぐれている。

長尾の考方方に打いては，粉体層はやはり均一球によ ってランダムに充てんされているが，等方応力といら仮 


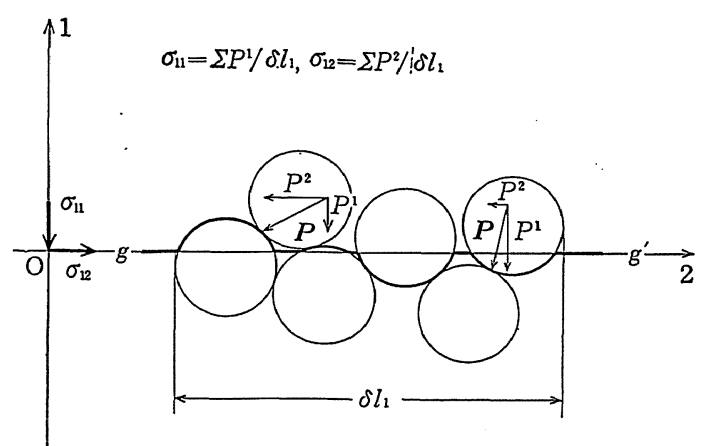

Fig. 8 応力と力の関係

定はとりのぞかれている。まず長尾の基本的な考え方を 説明する。一般 $i$ 軸に垂直な平面 $\overline{g g^{\prime}}$ 上で $j$ 方向に作 用する応力 $\sigma_{i j}$ は, 曲面 $\widetilde{g g^{\prime}}$ 上の接触点に働く力の $j$ 方向成分 $P^{j}$ の総和として表される。いま平面 $\overline{g g^{\prime}}$ の面 積を $\delta S_{i}$ とすれば，次式で表される。

$$
\sigma_{i j} \delta S_{i}=\sum_{\delta S_{i}} P^{j}
$$

この(19)式を，Fig. 8 に示したような 2 次元粉体層を例に とって説明する。いま, 粉体層中に 1 軸に垂直な平面 $\overline{g g^{\prime}}$ を考光, この平面に作用する応力と接触点働く力 の関係を求める。平面 $\overline{g g^{\prime}}$ に作用する応力としては, 垂 直応力である $\sigma_{11}$ と剪断応力である $\sigma_{12}$ がある。このと き長さ $\delta l_{1}$ の粉体層に働く垂直力 $\sigma_{11} \delta l_{1}$ は, 長さ $\delta l_{1}$ 内 にある接触点に働くカの 1 方向成分の総和 $\sum P^{1}$ に等し く, 剪断力 $\sigma_{12} \delta l_{1}$ は接触点に働く力の 2 方向成分の総 和 $\Sigma P^{2}$ に等しいというのが, (19)式の意味する所である。 この(19)式を具体的に解くわけであるが，これまで紹介 してきた考方方では切断球に着目してきたが，長尾の考 え方では，接触点を形成する球対に着目している。

いま, Fig.9 亿示すように $i$ 軸に対して $\xi_{i}$ だけ傾い た球対を考光，平面 $\overline{g g^{\prime}}$ より下側の球を $k$, 上側の球 を $l$ とする。Fig. 9 に示した傾き $\xi_{i}$ の球対は粉体層中 に数多くあるが，平面 $\overline{g g^{\prime}}$ が切断できるのは， Fig. 10 に示すように球 $k$ が平面 $\overline{g g^{\prime}}$ 上にある場合之球 $l$ が平 面 $\overline{g g^{\prime}}$ 上にある場合の間にある球対であり，その範囲 は $2 r \cos \xi_{i}$ となる。いま $\delta S_{i}$ の面積を基準にして考兄 ているので, 平面 $\overline{g g^{\prime}}$ が切断できる傾き $\xi_{i}$ の球対は,

体積 $\delta S_{i} 2 r \cos \xi_{i}$ の中に含まれることになる。したが って，単位体積中に含まれる接触点数を $\Lambda$ とすれば，曲 面 $\widetilde{g}^{\prime}$ 上に傾き $\xi_{i}$ の球対によって形成される接触点数 $N$ は次式で与えられる。

$$
N=2 \Lambda \delta S_{i} r \cos \xi_{i}
$$

一方，球対が傾き $\xi_{i}$ をるる確率 $p$ は， $\xi_{i}$ は 0 から $\pi$ /2 まで変化するので, Fig.11から明らかなように, 半

Vol. 21 No. 1 (1984)

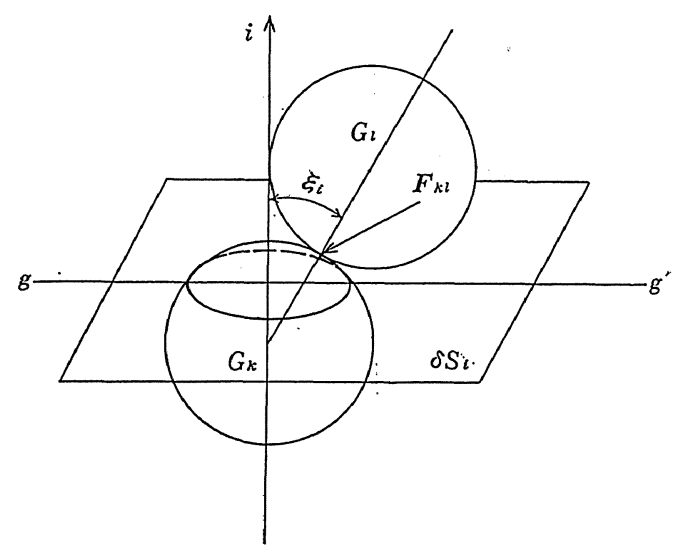

Fig.9 接触球対

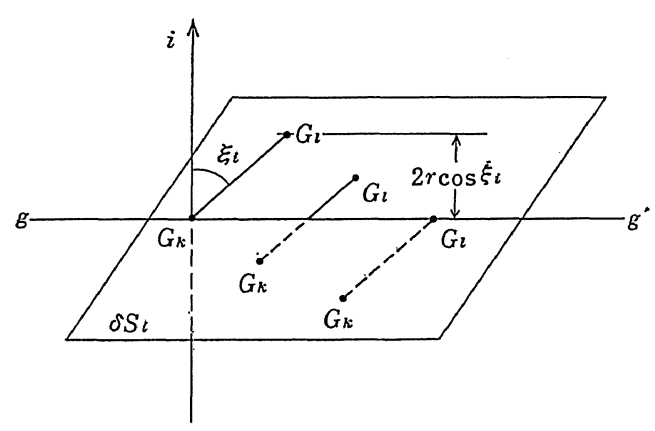

Fig. 10 球刘の在存籁四

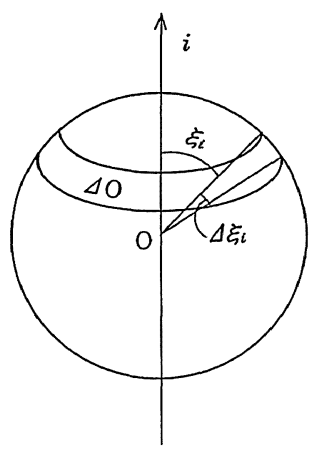

Fig. 11 球対の在存碓率

球の表面積と(7)式で求めた $\Delta O$ の比で与えられ, 次式で 表される。

$$
p=\frac{\Delta O}{2 \pi r^{2}}=\sin \xi_{i} \Delta \xi_{i}
$$

したがって，傾き $\xi_{i}$ の接触点において伝達される力の $j$ 方向成分の総和は, 次式で与えられる。

$$
\sum_{\delta S_{i}} P_{\xi_{i}}{ }^{j}=N p P^{j}=\Lambda r \delta S_{i} P^{j} \sin 2 \xi_{i} \Delta \xi_{i}
$$

よって，(19)式の右辺は(22)式を $0 か ら ~ \pi / 2$ まで積分すれ 


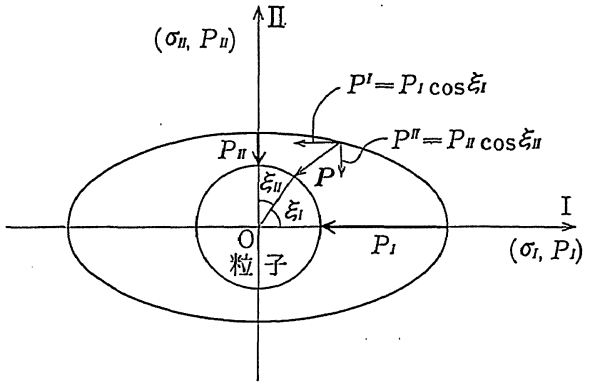

Fig.12 代表球回りの力の分布

ば求められる。

$$
\sum_{\delta S i} P^{j}=\int_{0}^{\pi / 2} \sum_{\delta S i} P_{\xi i}^{j} \mathrm{~d} \xi_{i}=\Lambda \delta S_{i} r \int_{0}^{\pi / 2} P^{j} \sin 2 \xi_{i} \mathrm{~d} \xi_{i}
$$

(19)，(23)式より $i$ 軸に垂直な面で $j$ 方向仵用する応力 $\sigma_{i j}$ は, 結局接触点に働く力の $j$ 方向成分 $P^{j}$ によって 次のよらに求められることになる。

$$
\sigma_{i j}=\Lambda r \int_{0}^{\pi / 2} P^{j} \sin 2 \xi_{i} \mathrm{~d} \xi_{i}
$$

この(2A)式を，いかなる面でも剪断応力は作用しない等 方応力といら仮定のもとで導かれた結果と比較するた め, 剪断力の作用しない面, 一なわち主応力面で考えて みる。(24)式中の $P^{j}$ は接虽点位置の関数となるため, こ のままでは(24)式を計算することはできない。そこで，長 尾は球面上に㰾く力も応力と同じように棈円分布をして いるといら仮定を導入している。この仮定は，Fig. 2 に 示したように，等方応力の場合には球面上に働く力が一 様に球の中心に向って㰾くといら仮定と, 同じ考え方と いえる。この仮定を導入すると，Fig. 12 に 2 次元的に 示したよらに，主応力軸 $J$ 軸 $(J=I ， \mathbb{I}, \mathbb{I})$ から $\xi_{J}$ の角度をなす接触点に働く力 $P$ の $J$ 方向成分 $P^{J}$ は次 式で与えられる。

$$
P^{J}=P_{J} \cos \xi_{J}
$$

ここで $P_{J}$ は主軸方向に働く力で, 球面上に働く力の主 値である。

これで(24式中の $P^{j}$ を位置の関数として与えることが できたので，(24)式右辺の積分は可能となる。いま，坐標 軸を主応力軸にとっているので，(24)式は次のように書き 改められる。

$$
\sigma_{J}=\Lambda r \int_{0}^{\pi / 2} P_{J} \cos \xi_{J} \sin 2 \xi_{J} \mathrm{~d} \xi_{J}
$$

(26)式右辺の積分は容易に行ならことができ，次式を得 る。

$$
\sigma_{J}=\frac{2 \Lambda r}{3} P_{J}
$$

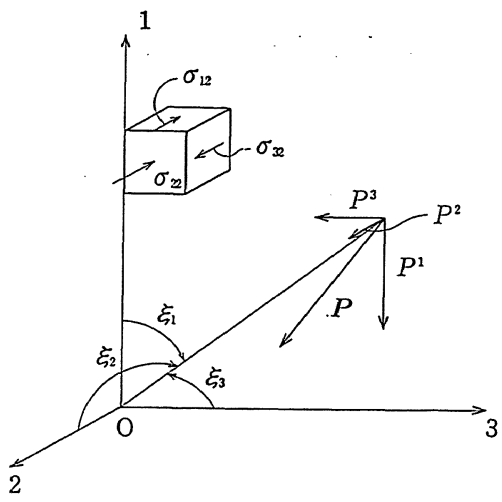

Fig. 13 一般座標系

これが長尾の最終結果であるが， Rumpf 式と比較する ために次のような変形を行なう。 1 は単位体積中の接触 点数であるから，次式によって空吵率 $\varepsilon$ と配 位 数 $k$ の 関係で次のように与えられる。

$$
\Lambda=\frac{1-\varepsilon}{4 \pi r^{3} / 3} \frac{k}{2}
$$

この式を(27)式に代入すれば，Rumpf 式とまったく同じ 次式が得られる。

$$
\sigma_{J}=\frac{1-\varepsilon}{\pi} k \frac{P_{J}}{d^{2}}
$$

また(24)式とは逆に，Fig.13 に示すような一般座標系 で，各軸から角 $\xi_{i}(i=1 ， 2 ， 3)$ の位置にある接触点に 働く力の $j$ 方向成分は, $j$ 方向に作用する応力 $\sigma_{i j}(i=$ 1，2，3）によって次式で与えられる。

$$
P^{j}=\frac{3 \sum_{i} \sigma_{i j} \cos \xi_{j}}{2 \Lambda r}
$$

\section{4 金谷 ${ }^{6)}$ の考え方}

金谷は，ここでは誘導を省略するが，仮想仕事の原理 を用いて(30)式に一致する関係式を導出している。いま， 主応力軸を座標軸とすると，座標軸に垂直な面では剪断 力は作用しないので $I \neq J$ なら $\sigma_{I J}=0$ となる。した がって，(30)式は次式となる。

$$
P^{J}=\frac{3 \sigma_{J} \cos \xi_{J}}{2 r \Lambda}
$$

(31)式の左辺を(25)式で書き改め，整理すれば(27)式に，した がってRumpf 式に一致する次式を得る。

$$
P_{J}=\frac{3 \sigma_{J}}{2 \Lambda r}
$$

さらに，これまでのいずれの考え方においても，球面 上の接触点分布は一様としてあつかってきたが，金谷 は，接触点分布は主応力方向に，その主応力の大きさに ほぼ比例して增大する傾向がある7、8)いう実験事実より， 


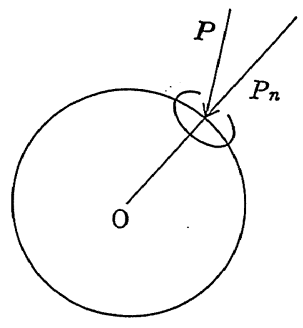

Fig. 14 接触面に動く力の法線方向成分

平均接触点分布密度が Fig.14 に示すように，接触点に 接する単位面積に働く力 $P$ の法線方向成分 $P_{n}$ に比例 するとして，接触点分布を考慮している。接触点の分布 を考慮すると(32)式は次のようになる。

$$
P^{J}=\frac{3}{2 \Lambda r} \sigma_{J} \cos \xi_{J} \frac{\sum_{K} \sigma_{K}}{3 \sum_{K} \sigma_{K} \cos ^{2} \xi_{K}}
$$

\section{Rumpf 式の新たな解䣋}

Rumpf 式はこれまで引張り破断に関する理論として 知られてきたが，上述のように，様々な考方方によって 誘導されてきた応力と力の関係式が Rumpf 式に一致 することより，Rumpf 式は応力と力の関倸を表す一般 式であると結論できる。

Rumpf 式の物理的意味は，(29)式によって明らかにさ れている。すなわち，(29)式は球表面に働く力の分布が応 力棈円と相似な楕円で表されることを示している。この ことは，球表面に働くカもまたテンソルとなり，応力テ ンソルと線形に関係づけられることを示している。した がって主軸で得られた(29)式は，一般座標系でも成立する ことになり次式のよらにより一般化される。

$$
\sigma_{i j}=\frac{1-\varepsilon}{\pi} k \frac{P_{i j}}{d^{2}}
$$

Fig.15に示すように，(34)式を用いるば $i$ 軸方向の接触

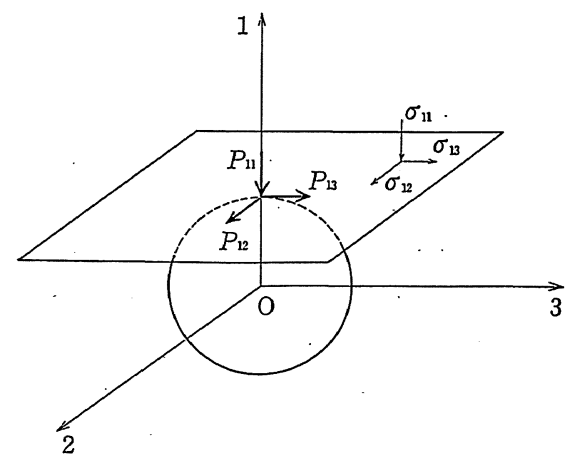

Fig. 15 Rumpf 式の物理的意味

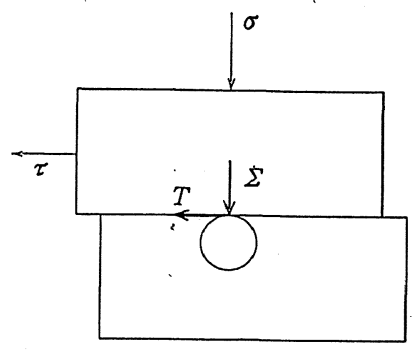

Fig.16 Rumpf 式の斯断試験への応用

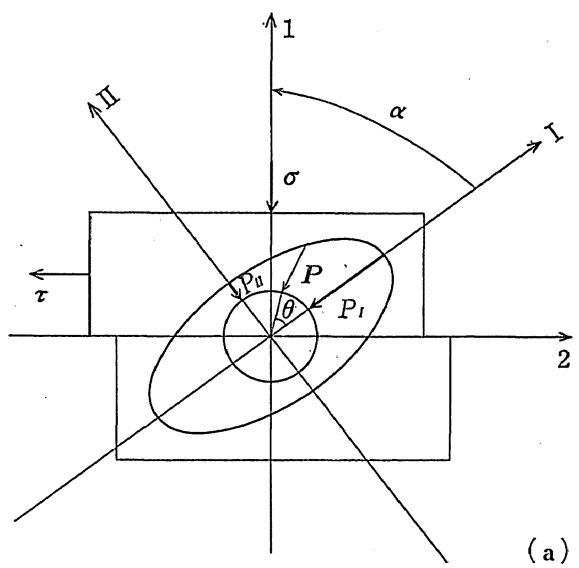

(a)

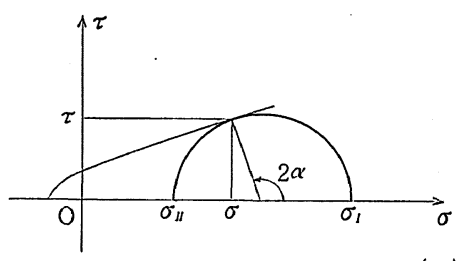

(b)

Fig.17 Rumpf 式の剪断試匰への忘用

点に働く力の 3 方向成分 $P_{i i}, P_{i j}, P_{i k}$ が， $i$ 軸に垂㨁 な平面に作用する 3 つの応力 $\sigma_{i i}, \sigma_{i j}, \sigma_{i k}$ から求めら れることになる。

\section{Rumpf 式の応用}

Rumpf 式は，応力と力の関係を表す一般式であるこ とがわかったため，極めて応用筈团の広い実用価值の，高 い理諭式となった。ここでは，粉体層の力学的特性を調 べる代表的な試騟法である, 剪断, 圧密, 引張り試験に 対して，どのように Rumpf 式の適用が可能かを紹介 する。

\section{1 剪断試験への応用}

Fig.16 に示すように，剪断面に接する 粒子接触点に 働く圧縮力 $\Sigma$ と剪断力 $T$ が, ‘(34)式を用いれば, 垂直応 
力 $\sigma$ と剪断応力 $\tau$ から次のように求められる。

$$
\begin{aligned}
& \Sigma=\frac{\pi d^{2}}{1-\varepsilon} \frac{\sigma}{k} \\
& T=\frac{\pi d^{2}}{1-\varepsilon} \frac{\tau}{k}
\end{aligned}
$$

また，Fig.17(b)に示すように，応力のモール円を描 くことができれば，主軸を決定することができるので，

Fig. 17(a)に示すように，粒子表面の任意の位置に働く 力も求められることになる。具体的には次の手順によれ ばよい。まず，モール円が決まれば主応力 $\sigma_{J}(J=1$ ，

II ) は求められるので(29)式によって力の主值 $P_{J}$ は求め られる。次に力 $P$ もテンソルであるから，主軸から任 意に $\theta$ だけ傾いた接触点に働くカの主軸方向成分 $P^{J}$ は 次式によって求められる。

$$
\left(\begin{array}{l}
P^{\mathrm{I}} \\
P^{\mathrm{II}}
\end{array}\right)=\left(\begin{array}{cc}
P_{\mathrm{I}} & 0 \\
0 & P_{\mathrm{II}}
\end{array}\right)\left(\begin{array}{l}
\cos \theta \\
\sin \theta
\end{array}\right)
$$

このように，Rumpf 式を用いれば，簡単に粒子表面 に働く力を応力から計算できるので，構成粒子に着目し た剪断機構のミクロな解析には, 極めて有効な武器にな ると思われる。

\section{2 圧密試験への応用}

圧密試験の場合にも剪断試験の場合と同様に, 沁力か ら粒子表面に働く力を計算できることは当然である。

圧密実験の結果は，空隚率と圧密応力の関係で表され る。この圧密特性の解析に扒いても，Rumpf 式が非常 に有効であることを紹介する。

Rumpf 式は， $k \varepsilon=\pi$ を仮定すると次のように書き換 えられる。

$$
\sigma_{i j}=\frac{1-\varepsilon}{\varepsilon} \frac{P_{i j}}{d^{2}}
$$

(38)式中の空吵率関数は，Fig.18 に示すようにかなり広 い笵囲に执いて，次式で近似される9 。

$$
\frac{1-\varepsilon}{\varepsilon} \simeq 10 \exp (-4.5 \varepsilon)
$$

したがって，(38)式は次のようなあつかいやすい式に書き 改めることができる。

$$
\sigma_{i j}=10 \exp (-4.5 \varepsilon) \frac{P_{i j}}{d^{2}}
$$

この式を圧密試験に適用する場合は，圧密応力 $p$ と圧 密応力方向に働く力 $P$ の関係になるから次式となる。

$$
p=10 \exp (-4.5 \varepsilon) \frac{P_{i j}}{d^{2}}
$$

一方, 圧密特性である圧密応力 $p$ と空陌率 $\varepsilon$ の関係 は，Fig. 199に示すように，片対数紙上で直線関係にな る場合が多い。そこで，いま圧密応力ゃを增大しても 接触点にかかる力 $P$ が増大しない場合を考えてみると，

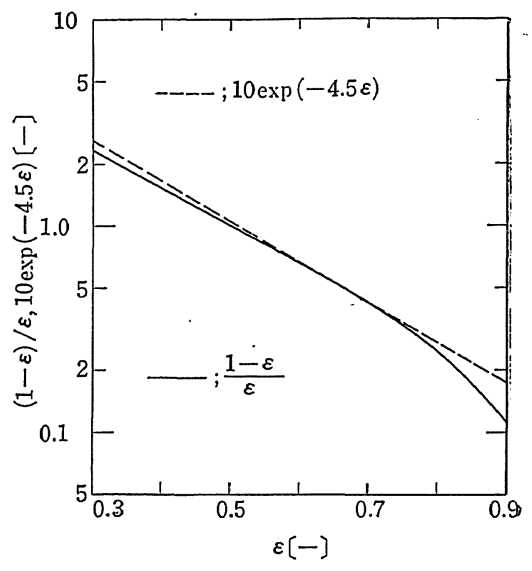

Fig. 18 空隐率関数の近似式

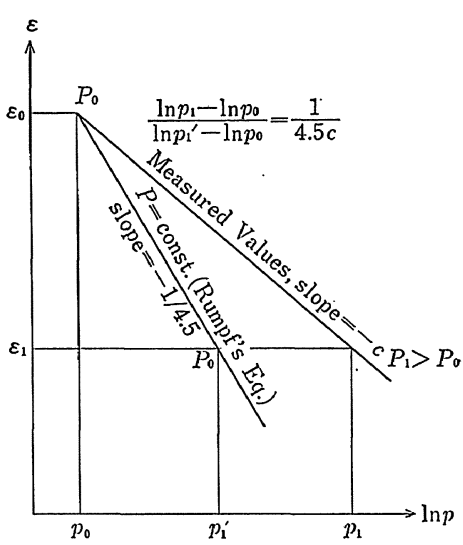

Fig. 19 圧密特性の Rumpf 式による解析

(41)式から明らかなと拉り圧密特性の傾き $\partial \varepsilon / \partial \ln p$ は -1/4. 5 となる。この - 1/4.5 という傾きの值をうまく 使うと, Fig.19 に示したように，圧密応力の增大によ る空隙率の減少と接触点に儌く力の增大を, 定量的に区 別することができる。Fig.19 亿おいて，任意の基準圧密 応力 $p_{0}$ から傾き $-1 / 4.5$ の直線を引くと, この直線は, 圧密応力の $p_{0}$ からの增大分は, 接触点数の増加（空 隙 率の減少)のみによって伝達されることを意味する。い まある空吵率において，接触点数の增加のみによって伝 達加能な圧密応力を $p_{1}{ }^{\prime}$ とし，実測值を $p$ とすれば， $p_{1}{ }^{\prime}-p_{0}$ は接触点数の増加のみによって堌大した圧密応 力を表し， $p_{1}-p_{1}{ }^{\prime}$ は接触点にかかる力の增大による圧 密応力增加分を表している。

これを数式によって表現すれば次のようになる。ここ で想定しているのは, 圧密実験結果が次の実験式で整理 される場合である。 


$$
p=k_{1} \exp (-\varepsilon / c)
$$

ただし， $k_{1} ， c$ は実験定数である。この式から明らかな ように，空吵率をさらに $\Delta \varepsilon$ だけ減少させるために必要 な压密応力の增加割合 $\Delta \ln p(=\Delta p / p)$ は，次式で与兄 られる。

$$
\mathrm{d} \ln p=-\mathrm{d} \varepsilon / c
$$

一方，接触点に働く力 $P$ が一定のまま圧密されるとし

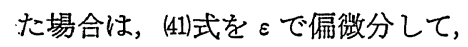

$$
(\partial \ln p)_{P}=-4.5 \partial \varepsilon
$$

が得られる。ここで(43)，(44)式の比をとれば，

$$
\left(\frac{\mathrm{d} \ln p}{\mathrm{~d} \varepsilon}\right) /\left(\frac{\partial \ln p}{\partial \varepsilon}\right)_{P}=\frac{1}{4.5 c}
$$

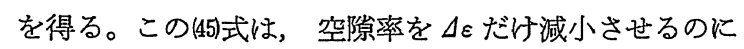
必要とされた圧密応力の增加割合は, 接触点に働く力を 一定にして圧密した場合の圧密応力增加割合の何倍にな るかを表わしている。このことを Fig.19 と対比させれ ば，次のようになる。

$$
\frac{\ln p_{1}-\ln p_{0}}{\ln p_{1}{ }^{\prime}-\ln p_{0}}=\frac{1}{4.5 c}
$$

したがって, 圧密試験の結果を空吵率のみならず接触 点にかかる力によっても，定量的に解析できることにな る。

\section{3 引張り試験への応用}

引張り破断試験は, Rumpf 式のいわば“発祥の地” で あるが，Rumpf 式の新たな解勫によって，従来よりは るかに有効な利用が可能になる。すなわち，粉体層の引 張り強さに対する, 空吵率 (接触点数) と1接触点当り の付着力の奇与を, 分離して定量的に解析評価できるこ とである。その解析は, 圧密試験の場合と同様に，次の ようにして行なわれる。

引張り試験の場合, 一般式である(40)式は, 引張り強さ $\sigma_{z}$ と 1 接触点当りの付着力 $H$ の関係式として, 次のよ らに畫き改められる。

$$
\sigma_{z}=10 \exp (-4.5 \varepsilon) \frac{H}{d^{2}}
$$

ここで, 付着力 $H$ が空吵率 $\varepsilon$ にって变化しないと仮 定すると, 引張り強さ $\sigma_{z}$ と空隙难 $\varepsilon$ の関係は, Fig. 20 炕示すように，片対数紙上で傾き -4.5 の直線となる。 一方, 数多くの実験結果 $\left.{ }^{9}{ }^{12}\right)$ は, 引張り強さ $\sigma_{z}$ 之空隙 $\varepsilon$ の関係が，次の実験式で整理されることを示している。

$$
\sigma_{z}=k_{2} \exp (-\varepsilon / b)
$$

ただし， $k_{2} ， b$ は定数である。したがって，実測値も片 対数紙上にプロットするなら，Fig. 20 に示したように， 傾き $-1 / b$ の直線でよく相関される。

ここで, 空吵率が $\varepsilon_{0}$ で引張り強さが $\sigma_{z 0}, 1$ 接触点 当りの付着力が $H_{0}$ の粉体層を, 空吵率 $\varepsilon_{1}$ まで圧密し

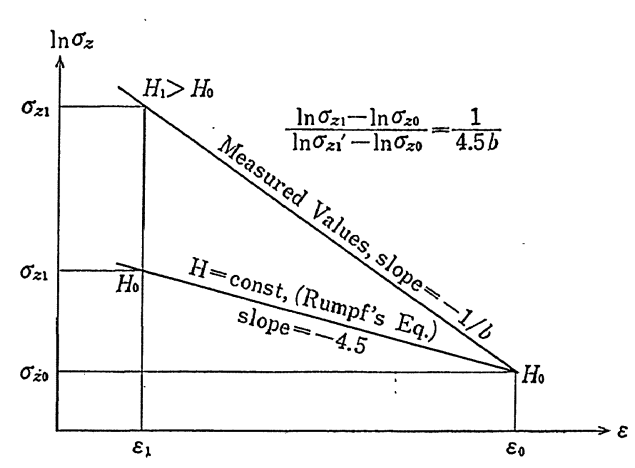

Fig. 20 引張り強さの Rumpf 式による解析

た時の引張り強さについて考えてみる。いま, $\varepsilon_{0} か ら \varepsilon_{1}$ までの珐密によっても，付着力は $H_{0}$ で一定であると考 えると，Fig. 20 から明らかなよらに，引張り強さは $\sigma_{z 0}$ から $\sigma_{z 1}{ }^{\prime}$ まで增大する。つまり， $\sigma_{z 1}-\sigma_{z 0}$ は空隙率 の減少（接触点数の增大）のみによる, 引張り強さの增 加を表わしている。それに対して実測值では， $\sigma_{z 0}$ から $\sigma_{z 1}$ まで増大しているので, $\sigma_{z 1}-\sigma_{z 1}{ }^{\prime}$ は付着力の增加 による引張り強さの增大を表わしていることになる。 したがって，圧密試験の場合と同様に，

$$
\frac{\ln \sigma_{z 1}-\ln \sigma_{z 0}}{\ln \sigma_{z 1}{ }^{\prime}-\ln \sigma_{z 0}}=\frac{1}{4.5 b}
$$

を求めることによって, 空吵率の变化による引張り強さ の変化割合を，接触点数の増加によるものと， 1 接触点 当りの付着力の增加によるものに分離して, 定量的に解 析評価できることになる。

\section{4. 具体的応用例 ${ }^{13)}$}

われわれは，3.2，3.3で紹介した解析法を，粉体層の 引張り破断試験に適用して, 興味樑い結果を得ているの で, 要約して紹介する。

粉体層の引張り強さを測定する場合, 空隙率は予圧密 によって調整されるので，引張り破断試験で得られる測 定データには，圧密特性も含まれて打り，压密特性，引 張り強さについての解析, また両者の関係についての解 析も可能となる。

われわれの研究室で得られた22の測定データが, Fig. 21，22にその 1 例を示したように，圧密特性技よび引張 り強さに関する実験式(42)，(48)式で相関されることを確 め, $(4.5 b)^{-1},(4.5 c)^{-1}$ の值を求めてみた。その結果 をFig. 23 に示したが，引張り試験の堭合 $(4.5 b)^{-1}$ の 值は約 3 から7で, 空隙率の変化による引張り強さの変 化割合に対しては，1接触点当りの付着力の增大が, 極 めて大きな役割を果していることがわかる。 


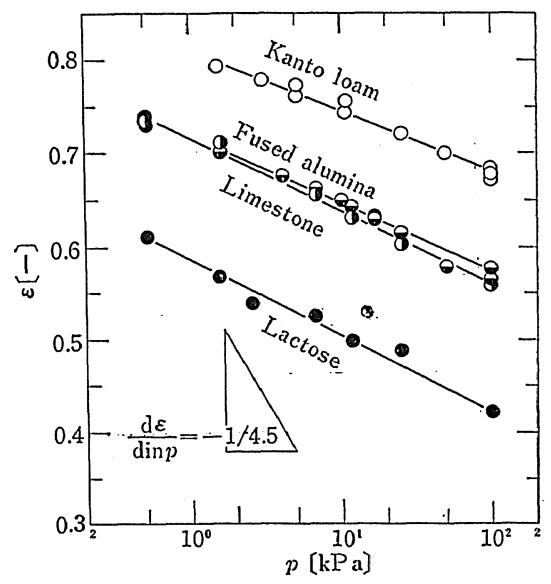

Fig. 21 圧密特性

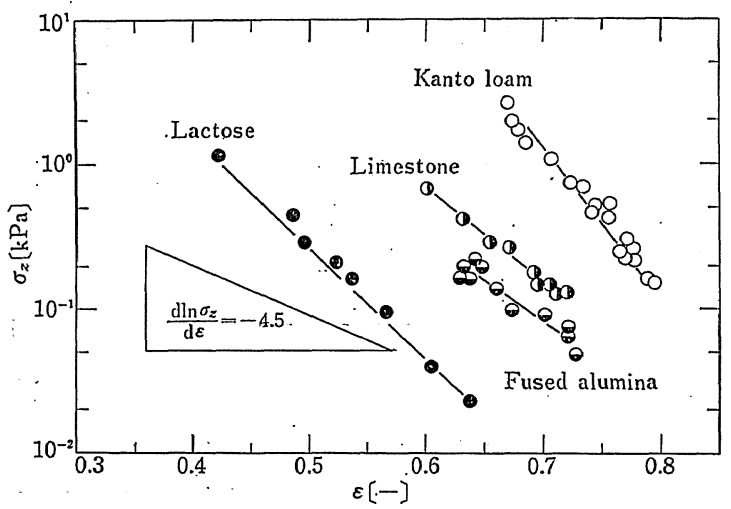

Fig. 22 引張り強さ

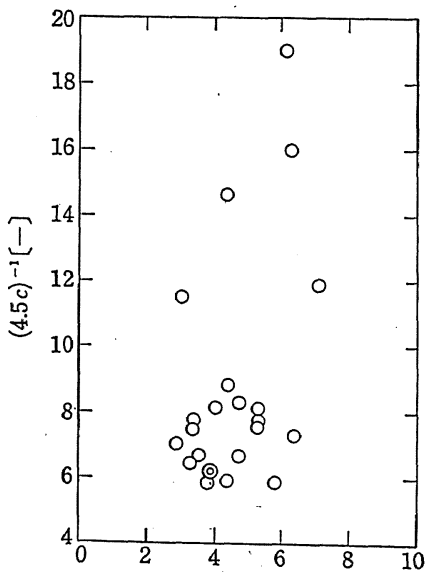

$(4.5 b)^{-1}\{-\}$

Fig. 23 粒子接触点に働く力の重要珄

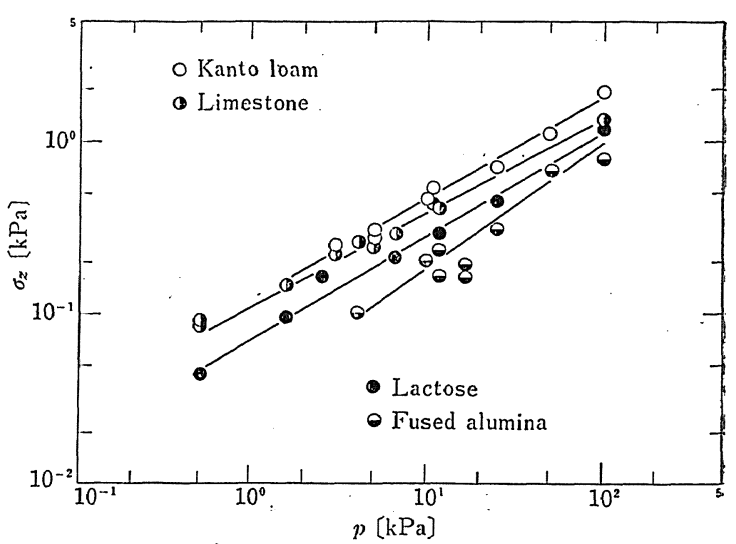

Fig. 24 引張り強さと予圧密応力

一方，圧密試験の場合 (4.5c)-1 の值は約 6 から19で， 圧密応力の変化割合に及ぼす空㗂率の変化の奇与はほん のわずかで，圧密応力の変化は，ほとんぞ粒子接触点に 働く圧縮力の変化によって生じていることがわかる。

次に，圧密特性之引張り強さの関係について若干考察 してみる。引張り強さ $\sigma_{z}$ と予圧密応力 $力$ の関係は，

Fig. 24 にその 1 例を示したように，次の実験式で表わ される。

$$
\sigma_{z}=k_{3} p^{m}
$$

ただし， $k_{3}, m$ は定数。さらに理諭的考察から，(50)式 は次式のように接触点に働く力関係を表わすことも，明 らかにしている。

$$
H=k_{3} P^{m}
$$

(50)式の予圧密応力 $p$ をある近似のもとに，(38)式によっ て接触点に働く圧縮力 $P$ に書き改めると, 引張り強さ に関する次の半理論式を得る。

$$
\sigma_{z}=\frac{1-\varepsilon}{\varepsilon} k_{3}\left(\frac{P}{\dot{d}^{2}}\right)^{m}
$$

Fig. 23 に示した結果と, 半理論式(52)式によって，予 圧密と引張り強さの関係を，次のように考えることがで きる。昐体層を予圧密すれば，空吵率は減少し接触点数 は增大するが，Fig.23の（4.5c) $)^{-1}$ の值は，それにむ 增して粒子接触点に働く圧縮力 $P$ が增大するこ・とを示 している。圧縮力 $P$ と付着力 $H$ は(51)式で関係づけられ るから， 压縮力 $P$ の増大はすなわち付着力 $H$ の増大を 意味し, Fig. 23 の $(4.5 b)^{-1}$ の值が 1 よりはるかに大 きくなるのである。

この解析結果は, 粉体層の空隙率調整を目的にして行 なら予圧密が，空吵率を減少させるだけでなく，粒子接 触点に働く圧縮力をも增大させていること，そして粉体 層の引張り強され対しては，空吵率よりも圧縮力の方が 
極めて重要な因子であることを示している。このこと は，空吵率が等しくともその調整法が異なっていれば， 粉体層はまったく異なる引張り強さを持つことを意味 し，空隙率のみによって粉体層の引張り強さを整理する ことには，問題があることを示している。

より一般的にいえば，現在粉体層の力学的特性を表わ 寸パラメータとして空陵率が広く用いられているが，粉 体層の力学的特性は，空嚐率によって代表されるもので はまったくなく，粒子接触点に働く力によっても評価さ れるべきであるといえる。この粒子接触点に働く力を考 慮に入れた現象の解析と, その評価法の確立が粉体層力 学の今後の重要な課題であると思われる。

\section{おわりに}

以上 Rumpf 式と，粉体層の応力と粒子接触点に働く 力を関係づるいくつかの理論式を詳細に紹介しなが ら，Rumpf 式は従来考えられていたよらな引張り強さ に関する理論式ではなく，単に粉体層に作用する応力と 接触点に働く力の関係式であることを明らかにした。

しかし，Rumpf 式の適用範囲が，従来考えられてい た引張り応力から，圧縮応力や剪断応力を含めた応力一 般に拡張されるため，Rumpf 式は極めて応用範囲が広

引用 文 献

1) Rumpf, H. : Chem. Ing. Tech., 30, 144(1958)

2) Rietsch, W. and H. Rumpf : ibid, 39, 885(1967)

3) Molerus, O.: Powder Technology, 12, 259(1975)

4) Rumpf, H.: Chem. Ing. Tech., 42, 538(1970)

5）長尾高明：機械学会諭文集，43，4038(1977)

6) 金谷健一：粉体工学誌, 17, 504(1980)

7) Oda, M. : Solids and Foundations, 12, 1(1972)

8) Oda, M. and J. Konishi: ibid, 14, 25(1974)

9) Jimbo, G. and R. Yamazaki : European Symposium
く，実用価值の高い理論式であることを明らかにした。

また，Rumpf 式が様々な考方方によっで誘導された 理論式と完全に一致することから, 均一球によってラ ンダムに充てんされた粉体層といら仮定のもとでは, Rumpf 式はゆるぎない理論式であるということができ る。

したがって Rumpf 式は，実测可能であるマクロな 情報を基礎にして，ミクロな視点から粉体層の力学的挙 動を解析する上で, 強力な武器となるものである。ここ では, 粉体層の力学的特性の代表的試験法に対して, い くつか応用法を例示し, 引張り試験結果の解析に具体的 に適用した例によって，その威力の一端を紹介した。

粉体層力学が他からの借りものでなく, 独自の力学体 系を持つためには，粉体の不連続性とその不連続面での. 現象が定量的にとりあつかわなければならない。この 「不連続」の問題解決に対して, Rumpf 式がいかんな くその実力を発揮してくれることを期待したい。

\section{謝. 辞}

ここで紹介した内容は, 本学会「汾体操作に伴ら諸現 象に関する勉強会」での伊ヶ崎文和氏の資料に負ら所が 大きい。伊ヶ崎氏始め勉強会メンバーの諸氏に，厚くお 礼申し上げる。

Particle Technology, B. 1064(1980 Amsterdam)

10) 大塚昭信, 檩上和美 : 粉体工学会誌, 18，591(1981)

11) 椿淳一郎, 加藤啓一, 神保元二: 粉体工学会誌, 1, 873 (1980)

12) Jimbo, G. and S. Hatano: the Fine Particle Society Pacific Region Meeting (1983 Hawaii)

13) Tsubaki, J. and G. Jimbo: Powder Technology, 37, 219 (1984) 